\title{
AKTIVITAS FISIK DENGAN KEJADIAN INSOMNIA PADA ATLIT GYM
}

\author{
Rafli Manggopa \\ Rina Kundre \\ Mario Katuuk \\ Program Studi Ilmu Keperawatan Fakultas Kedokteran \\ Universitas Sam Ratulangi \\ Email : rafli_manggopa@yahoo.com
}

\begin{abstract}
Insomnia is a difficulty in starting and maintaining sleep so someone cannot meet adequate sleep needs, both quantity and quality. Physical activity is a body movement produced by skeletal muscle which results in energy expenditure, regular physical activity has long been considered an important component in healthy living. The purpose of this study was to determine the relationship between physical activities and the incidence of insomnia experienced by Manado Global gym athletes. The research method used was observational analytic with cross sectional design. The sampling technique in this study was total sampling with 100 samples. Data collection is done using a questionnaire. The research result based on statistic test of Chi-Square test with the level of meaning $95 \%(\alpha=0,05)$ is presented on a table $2 \times 3$ with earned value $p=0,000$ which is smaller than $\alpha(0,05)$ with rejected Ho and accepted Ha. The conclusion shows that there is a correlation between physical activities and insomnia condition experienced by Global Manado gym athletes.
\end{abstract}

Keywords : Physical activity, insomnia incident

\begin{abstract}
Abstrak : Insomnia merupakan kesukaran dalam memulai dan mempertahankan tidur sehingga tidak dapat memenuhi kebutuhan tidur yang adekuat, baik kuantitas maupun kualitas. Aktivitas fisik merupakan gerakan tubuh yang dihasilkan oleh otot rangka yang mengakibatkan pengeluaran energi, aktivitas fisik secara teratur telah lama dianggap sebagai komponen penting dalam hidup sehat. Tujuan penelitian ini untuk mengetahui hubungan aktivitas fisik dengan kejadian insomnia pada atlit gym Global Manado. Metode penelitian yang digunakan yaitu observasional analitik dengan rancangan cross sectional. Teknik pengambilan sampel pada penelitian ini yaitu total sampling dengan jumlah 100 sampel. Pengumpulan data dilakukan menggunakan kuesioner. Hasil penelitian berdasarkan uji statistik Chi-Square test dengan tingkat kemaknaan 95\% $(\alpha=0,05)$ disajikan dalam tabel $2 \times 3$ diperoleh nilai $p=0,000$ yakni lebih kecil dibandingkan $\alpha(0,05)$ dengan Ho ditolak dan Ha diterima. Kesimpulan terdapat hubungan aktivitas fisik dengan kejadian insomnia pada atlit gym Global Manado.
\end{abstract}

Kata kunci : Aktivitas fisik, Kejadian Insomnia

\section{PENDAHULUAN}

Sepertiga umur manusia dihabiskan untuk tidur. Tidur merupakan kebutuhan dasar manusia yang bersifat fisiologis atau merupakan kebutuhan fisiologis atau merupakan kebutuhan paling bawah dari piramida kebutuhan.. Tidur dapat memulihkan fisik setelah seharian beraktivitas, mengurangi stress, menjaga keseimbangan mental dan emosional, serta meningkatkan kemampuan dan kosentrasi.
Kesulitan tidur, sering terbangun di malam hari, sulit untuk tidur kembali, dan bangun dini hari serta merasa tidak segar saat bangun pagi adalah gejala yang dialami oleh penderita insomnia (Saputra, 2013).

Gangguan tidur pada orang dewasa diperkirakan 20\%-50\% dilaporkan setiap tahun adanya gangguan tidur dan sekitar $17 \%$ mengalami gangguan tidur yang serius. Prevalensi gangguan tidur pada dewasa cukup tinggi yaitu sekitar $67 \%$ 
(World Health Organization, 2010). Di Indonesia, setiap tahun diperkirakan sekitar $35 \%-45 \%$ orang dewasa melaporkan adanya gangguan tidur dan sekitar $25 \%$ mengalami gangguan tidur yang serius. Prevalensi gangguan tidur pada dewasa cukup tinggi yaitu sekitar 50\% (Depkes RI, 2010). Virginia Henderson sebagai salah satu tokoh keperawatan mengemukakan sebuah model keperawatan yang dikenal dengan “The Activities of Living”. Menurut Henderson, kebutuhan dasar manusia terdiri atas 14 komponen yang merupakan komponen penanganan perawatan. Salah satu komponen yang termasuk dalam kebutuhan dasar manusia yang harus dipenuhi adalah kebutuhan akan tidur dan istirahat, dimana gangguan pola tidur merupakan salah satu contoh aplikasi teori konsep Henderson pada praktik keperawatan. Dengan kata lain, ketika seseorang mengalami gangguan pola tidur (insomnia), maka salah satu komponen penting dari kebutuhan dasar manusia tidaklah terpenuhi (Asmadi, 2005).

Aktivitas fisik merupakan setiap gerakan tubuh yang dihasilkan oleh otot rangka yang memerlukan pengeluaran energi. Jadi, kesimpulan dari pengertian aktivitas fisik ialah gerakan tubuh oleh otot tubuh dan sistem penunjangnya yang memerlukan pengeluaran energi. Ada tiga jenis aktivitas fisik : aktivitas fisik ringan, aktivitas fisik sedang, aktivitas fisik berat (Russel, 2005).

Program olahraga atau aktivitas fisik sangat bergantung pada kadar dari masing-masing tubuh seseorang factor fisiologis, emosional dan perkembangan akan mempengaruhi toleransi aktivitas. Secara garis besar ada beberapa kondis medis yang telah ditentukan sebagai penyebab insomnia, diantaranya ialah stress atau kecemasan, depresi, efek samping pengobatan, pola makan yang buruk, aktivitas tidak teratur. Olahraga yang teratur dapat meningkatkan fungsi tubuh seperti, fungsi jantung dan paru-paru (ketahanan), kebugaran otot dan tulang (fleksibilitas dan integritas tulang), serta kesejahteraan psikologis. Selain itu, dapat merangsang penurunan aktivitas saraf simpatis dan meningkatkan aktivitas parasimpatis yang berakibat pada penurunan hormone adrenalin, norepinefrin dan katekolamin yang menyebabkan rasa lelah pada tubuh manusia (Solso, 2008).

Pratama (2014) dalam jurnalnya menunjukan bahwa ada hubungan hubungan antara aktivitas fisik dengan angka kejadian insomnia, dimana dari 55\% dari aktivitas fisik terdapat $56,7 \%$ yang mengalami insomnia dari sebagian responden laki-laki 63,3\% dengan umur 1319 tahun 96,6\%. Berdasarkan kesimpulannya, bahwa ada dampak pada olahragawan atau atlit yang kelelahan mengalami gangguan tidur. Terdapat perbedaan pada orang yang beraktivitas fisik teratur dan tidak teratur, orang yang beraktivitas teratur akan mendapatkan kualitas tidur yang baik.

Maulidha (2017), dalam hasil penelitiannya menunjukan bahwa karakteristik responden didominasi oleh usia 19 tahun sebanyak 8 responden (32\%), mayoritas responden jenis kelamin laki-laki sebanyak 16 responden (64\%), frekuensi 3 kali seminggu sebanyak 8 reponden (32\%), sebagian besar responden di kategorikan dalam aktivitas sedang sebanyak 15 responden (60\%), dan mayoritas responden kualitas tidur buruk sebanyak 13 responden (52\%). Dalam hasil penelitiannya selaras dengan penelitian yang pernah dilakukan oleh Pratama (2014) tentang aktivitas fisik dan insomnia pada atlit judo.

Observasi awal peneliti yang dilakukan di Pusat kebugaran Gym di Global Manado pada bulan september 2018 dengan member yang aktif sebanyak 100 . Dari observasi dan hasil wawancara informal yang dilakukan peneliti pada 10 orang atlit, didapati 4 orang atlit mengalami insomnia dikarenakan mengangkat beban terlalu berat sehingga pada saat tidur otototot terasa pegal dan sering mengalami keram otot pada waktu tidur. Wawancara lebih lanjut pada 6 orang atlit, mereka mengatakan bahwa mereka mengalami 
insomnia 1 sampai 2 minggu karena pola aktivitas yang tidak teratur. Berdasarkan paparan latar belakang yang ditemukan, maka peneliti tertarik untuk meneliti Hubungan Aktivitas Fisik dengan Kejadian Insomnia pada Atlit Gym Di Global Manado.

\section{METODE PENELITIAN}

Penelitian ini termasuk dalam jenis penelitian kuantitatif dengan menganalisis gambaran hubungan antara kedua variabel yaitu variabel independen (Aktivitas Fisik) dan variabel dependen (Insomnia). Penelitian ini menggunakan desain penelitian cross sectional. Penelitian ini dilaksanakan di Gym Global Center Manado pada bulan November 2018 - Juni 2019. Populasi penelitian ini adalah seluruh member yang aktif sebanyak 100 . Pengambilan sampel menggunakan teknik total sampling.

Desain penelitian yang digunakan, desain penelitian berupa case control dengan pendekatan retrospektif. Penelitian case control atau kasus kontrol merupakan suatu penelitian survei analitik yang menyangkut bagaimana faktor resiko dipelajari menggunakan pendekatan retrospektif yang melihat kejadian masa lampau (Notoatmodjo, 2010).

Pengolahan data yang diperoleh dari hasil penelitian ini diolah secara manual dengan mengelompokkan hasil wawancara dan observasi kemudian dilakukan penghitungan skor dan dianalisis menggunakan uji statistik melalui sistem komuterisasi dengan beberapa tahap yaitu editing, coding, cleaning, tabulating (Notoatmodjo, 2010). Analisa bivariat dalam penelitian ini yaitu untuk mengetahui hubungan Aktivitas Fisik dengan Kejadian Insomnia Pada Atlit Gym. Peneliti menggunakan uji statistic Chi Square dengan tingkat kemaknaan $95 \%(\alpha=0,05)$.
HASIL dan PEMBAHASAN

1. Aktivitas Fisik

Tabel 1. Distribusi Responden Berdasarkan Aktivitas Fisik

\begin{tabular}{ccc}
\hline Aktivitas & n & \% \\
\hline Baik & 25 & 25,0 \\
Buruk & 75 & 75,0 \\
\hline Total & 100 & 100 \\
\hline
\end{tabular}

Sumber : Data Primer 2019

Hasil analisis pada tabel 1 menunjukkan bahwa dari 100 responden, responden terbanyak mengalami aktivitas buruk dengan jumlah 75 responden $(75,0 \%)$, kemudian sisanya aktivitas baik dengan jumlah 25 reponden $(25,0 \%)$.

Aktivitas fisik merupakan sekumpulan gerakkan yang dilakukan oleh otot tubuh dan sistem penunjangnya. Setiap gerakan tubuh dihasilkan oleh otot yang memerlukan energi (Russel R, 2005). Kristanti (2002) menyebutkan bahwa untuk mendapatkan hasil yang maksimal, aktivitas fisik harus dilakukan dalam porsi yang tepat. Semakin tinggi tingkat aktivitas fisik diperkirakan akan memberikan manfaat lebih pada kesehatan namun kenyataannya hanya akan meningkatkan resiko cedera pada seorang atlit.

Penelitian Maulidha (2017), dalam jurnalnya Hubungan Aktivitas Fisik dengan Kualitas Tidur, dimana sebagian besar responden dikategorikan dalam aktivitas fisik berat sebnyak 15 responden $(60,0 \%)$ dan aktivitas sedang sebnyak 13 responden $(52,0 \%)$. Jurnal tersebut juga menyatakan bahwa penelitiannya selaras dengan penelitian yang dilakukan oleh Nugroho (2016) bahwa seseorang yang melakukan aktivitas fisik atau latihan yang terlalu berat maka akan menyebabkan gangguan pada pola tidurnya yang selanjutnya akan berdampak pada kualitas tidur yang buruk. Dari 60 responden terdapat 33 responden yang berkategori aktivitas fisik tinggi mengalami gangguan tidur yang berpengaruh pada kualitas tidur. 


\section{Kejadian Insomnia}

Tabel 2. Distribusi Responden Berdasarkan Kejadian Insomnia

\begin{tabular}{ccc}
\hline Kejadian Insomnia & $\mathbf{n}$ & $\mathbf{\%}$ \\
\hline $\begin{array}{c}\text { Insomnia sementara } \\
\text { Insomnia Jangka } \\
\text { Pendek }\end{array}$ & 7 & 7,0 \\
Insomnia Jangka & 57 & 57,0 \\
Panjang & 36 & 36,0 \\
\hline Total & 100 & 100 \\
\hline Sumber : Data Primer 2019
\end{tabular}

Analisis pada tabel 2 menunjukkan bahwa dari 100 responden, responden terbanyak mengalami insomnia jangka pendek dengan jumlah 57 responden (57,0\%) kemudian sisanya insomnia jangka penjang dengan jumlah 36 responden (36\%) dan insomnia sementara dengan jumlah 7 responden $(7,0 \%)$.

Insomnia merupakan kesukaran dalam memulai dan mempertahankan tidur sehingga tidak dapat memenuhi kebutuhan tidur yang adekuat, baik kuantitas maupun kualitas. Keadaan ini merupakan keluhan tidur yang paling sering dijumpai, baik yang bersifat sementara maupun persisten. Insmnia yang bersifat sementara umumnya berhubungan dengan kecemasan dan kegelisahan (Saputra, 2013).

Pate (2005) menyatakan bahwa seseorang yang memiliki aktivitas fisik terlalu tinggi akan menyebabkan gangguan tidur pada masa jatuh tidur sehingga seseorang tersebut dapat mengalami insomnia. Durasi untuk jatuh tidur yang lebih lama akan berefek samping pada saat bangun tidur, badan tidak menjadi bugar dan mengurangi waktu metabolisme tubuh.

Penderita gangguan sulit tidur atau insomnia kini makin banyak diderita kalangan usia muda. Saat ini banyak usia 20-30 tahun yang mengalami insomnia. Sekitar $30 \%$ orang dewasa mengalami insomnia sampai tingkat tertentu pada satu saat dalam hidupnya. Sekitar $10 \%$ punya masalah cukup parah yang mempengaruhi waktu jaga, menurut American Academy of Sleepy Medicine, yang menerbitkan panduan pengobatan insomnia dalam Journal of Clinical Sleep Medicine. Fakta tentang pola tidur orang dewasa amerika (National Sleep Foundation, Amerika Serikat), adalah lebih dari sepertiga (36\%) dewasa muda usia 18- 29 tahun dilaporkan mengalami kesulitan untuk bangun pagi, dibandingkan dengan 20\% pada usia 30-64 tahun dan 9\% di atas usia 65 tahun. Hampir seperempat dewasa muda (22\%) sering terlambat masuk kelas atau bekerja karena sulit untuk bangun di pagi hari dibandingkan dengan (11\%) pekerja usia 30-64 tahun dan (5\%) di atas usia 65 tahun. (4\%) dewasa muda mengeluhkan kantuk saat bekerja sekurang-kurangnya 2 hari dalam seminggu atau lebih, sedangkan pada usia 30-64 tahun (23\%) dan di atas usia 65 tahun (19\%).

\section{Hasil Analisa Bivariat}

Tabel 3. Hubungan Aktivitas Fisik dengan Kejadian Insomnia Pada Atlit Gym Global Manado

\begin{tabular}{|c|c|c|c|c|c|c|c|c|c|}
\hline \multirow{3}{*}{$\begin{array}{c}\text { Aktifitas } \\
\text { Fisik }\end{array}$} & \multicolumn{6}{|c|}{ Kejadian Insomnia } & \multirow{2}{*}{\multicolumn{2}{|c|}{ Total }} & \multirow{3}{*}{$P$} \\
\hline & \multicolumn{2}{|c|}{$\begin{array}{l}\text { Insomnia } \\
\text { Sementara }\end{array}$} & \multicolumn{2}{|c|}{$\begin{array}{c}\text { Insomnia } \\
\text { Jangka } \\
\text { Pendek }\end{array}$} & \multicolumn{2}{|c|}{$\begin{array}{l}\text { Insomnia } \\
\text { jangka } \\
\text { panjang }\end{array}$} & & & \\
\hline & $\mathrm{n}$ & $\%$ & $\mathrm{n}$ & $\%$ & $\mathrm{n}$ & $\%$ & $\mathrm{n}$ & $\%$ & \\
\hline Baik & 7 & 28,0 & 18 & 72,0 & - & - & 25 & 100 & \\
\hline Buruk & - & - & 39 & 52,0 & 36 & 48,0 & 75 & 100 & 0,00 \\
\hline Total & 7 & 28,0 & 57 & 57,0 & 36 & 36,0 & 100 & 100 & \\
\hline
\end{tabular}

Sumber : Data Prime tahun 2019

Analisis bivariat dalam penelitian ini dilakukan untuk menguji hipotesis hubungan aktivitas fisik dengan kejadian insomnia pada atlit gym Global Manado dengan menggunakan uji statistik ChiSqure dengan tingkat kemaknaan CI $=95 \%$ atau interval kepercayaan $\rho<0,05$. Menurut Hustanto (2007) jika tabel lebih dari 2x2 maka nilai dari per selnya tidak boleh lebih dari $20 \%$, dengan hasil yang didapat pada pengolahan data variabel independen dengan 2 kategori yaitu aktivitas baik dan buruk, serta variabel dependen dengan 3 kategori yaitu insomnia sementara, jangka pendek dan jangka panjang dengan 
menggunakan bantuan aplikasi komputer dengan tabel $2 \times 3$ didapatkan nilai per sel $16,7 \%$ yang lebih kecil dari $20 \%$ (dapat dilihat dilampiran). Menurut Hastono (2007), jika pada tabel lebih dari 2x2 maka dilakukan uji Pearson Chi-Square.

Hasil analisis pada tabel 3 menunjukkan bahwa dari 25 orang $(100,0 \%)$ responden yang merupakan aktifitas fisik baik terdapat 18 orang $(72,0 \%)$ responden yang mengalami insomnia jangka pendek dan terdapat 7 orang $(28,0 \%)$ responden yang mengalami insomnia sementara. Sedangkan dari 75 orang $(100,0 \%)$ responden yang merupakan aktifitas fisik buruk terdapat 36 orang $(48,0 \%)$ responden yang mengalami insomnia jangka panjang dan 39 orang $(52,0 \%)$ responden mengalami insomnia jangka pendek. Pada perhitungan uji ChiSquare Test dengan komputerisasi didapatkan bahwa $\rho$ value $=0,000$ dimana lebih kecil dari nilai $\alpha$ yang ditetapkan $(\alpha=$ $0,005)$. Berdasarkan hasil ini maka ada hubungan aktivitas fisik dengan kejadian insomnia pada Atlit Gym Global Manado.

Kegiatan harian atau kegiatan yang tidak terstruktur akan mempengaruhi pengurangan waktu tidur atau kualitas tidur. Salah satu cara untuk meningkatkan kualitas tidur dengan menjaga aktivitas fisik. Aktivitas fisik akan menyebabkan kelelahan yang kemudian menghasilkan protein DSIP (Delta Inducing Pepide Sleep) dan membuat kualitas tidur menjadi lebih baik. Latihan dan kelelahan dapat mempengaruhi kualitas dan kuantitas tidur dan akan mengalami insomnia jangka pendek. Keletihan akibat aktivitas yang tinggi memerlukan tidur yang lebih untuk menjaga keseimbangan terhadap energi yang telah dikeluarkan. Orang yang telah melakukan aktivitas dan mencapai kelelahan akan lebih cepat untuk tidur karena tahap tidur Non Rapid Eye Movement (NREM) diperpendek. (Wollfson, dkk, 2007).

Keletihan yang terjadi setelah melakukan aktivitas olahraga akan menimbulkan seseorang akan cepat tertidur.
Hal ini juga disebabkan oleh siklus tidur tahap gelombang lambatnya diperpendek. Sehingga akan lebih cepat masuk kedalam fase tidur atau mengalami tidur yang nyenyak. Sedangkan, gaya hidup yang berbeda seperti halnya kurang melakukan aktivitas atau maupun melebihi batas aktivitas yang diluar kemampuan tubuh masing-masing akan dapat berdampak buruk pada kualitas jam tidur (Sulistiyani, 2012).

Penelitian Herpendika dkk, (2018) tentang antara kebugaran jasmani dengan kualitas tidur didapatkan hasil bahwa mayoritas responden yang dikategorikan tidak bugar 24 responden $(63.0 \%)$, dan ratarata responden megalami kualitas tidur yang buruk sebnyak 28 responden $(73,7 \%)$. Ini menunjukkan bahwa ada hubungan antara kualitas tidur terhadap kebugaran jasmani. Penelitian tersebut sesuai dengan penelitian yang peneliti lakukan dimana hasilnya menunjukkan bahwa aktivitas buruk sebanyak 75 responden $(75,0 \%)$ dan yang men galami insomnia jangka pendek sebanyak 57 responden $(57,0 \%)$.

\section{SIMPULAN}

Teridentifikasi bahwa responden sebagian besar berada pada kategori aktivitas buruk. Teridentifikasi bahwa responden sebagian besar berada pada kategori insomnia ringan. Terdapat hubungan yang signifikan antara aktivitas fisik degan kejadian insomnia pada Atlit Gym Global Manado.

\section{DAFTAR PUSTAKA}

Asmadi. (2005). Konsep Dasar

Keperawatan. Jakarta: Buku

Kedokteran EGC.

Departemen Kesehatan RI. (2010). Profil Kesehatan Indonesia Tahun 2010. Jakarta: Bakti Husada.

Herpendika, P.R, dkk. (2018). Hubungan Antara Kebugaran Jasmani Dengan Kualitas Tidur. Skripsi Strata Satu Universitas Nusantara PGRI Kediri. Diakses pada tanggal 
e-journal Keperawatan(e-Kp) Volume 7 Nomor 2, Agustus 2019

10 juni 2019.

(http://ojs.unpkediri.ac.id/index.php /pjk).

Maulidha, Tegar.R.N. (2017). Hubungan Aktivitas Fisik dengan Kualitas Tidur Pada Mahasiswa UKM Tapak Suci. Yogyakarta: Universitas Mhammadiyah. Diakses pada tanggal 29 Agustus 2018. (http://repository.umy.ac.id/handle/ 123456789/15562).

National Sleep Foundation. (2018). School Start Time And Sleep. Diakses pada tanggal 10 Juni 2019. (https://sleepfoundation.org/sleepnews/school-start-time-and-sleep).

National Sleep Foundation. (2015). National Sleep Foundation Recommends New Sleep Times. (https://sleepfoundation.org/presrel ease/national-sleepfoundation_recommends-newsleep--times). Diakses pada 15 mei 2018.

Notoatmodjo, S. (2010). Metodologi Penelitian Kesehatan. Jakarta: Rineka Cipta.

Pate, R., dkk. (2005). Dasar-Dasar Ilmiah Kepelatihan (terjemahan Kasiyo Dwijowinoto). Semarang: IKIP Semarang Press.

Pratama, Gede Ngurah. (2014). Hubungan aktivitas fisik dengan Kejadian Insomnia Pada Atlet Judo di JAD Tiang Bendera Jakarta Barat. Skripsi Strata Satu, Universitas Esa Unggul.

Russel R. Pate. (2005). Physical Activity and Public Health. Recommendation From the Center for Disiase Control of Sport Medicine.

Saputra, L. (2013). Catatan Ringkas Kebutuhan Dasar Manusia. Jakarta: Binarupa Aksara. 